\title{
EFFETS DE L'INGESTION D'ENSILAGE DE LUZERNE SUR LA PHYSIOLOGIE DIGESTIVE DU VEAU PIÉCOCEMENT SEVRÉ
}

\author{
M. CANDAU \\ Chaire de Zootechnie et des Productions animales, \\ E. N. S. S. A. A., I. N. R. A., \\ 26, boulevard Docteur-Petitjean, \\ B. P. 588, 21016 Dijon Cedex
}

Nous avons comparé des régimes de sevrage à base d'ensilage (ensilage direct et ensilage préfané) ou de foin comme seul aliment grossier. Quel que soit le régime, I 4 semaines apparaît comme un âge important dans l'évolution de la physiologie digestive du jeune veau précocement sevré à 5 semaines ( à partir de cet âge, le jeune ruminant a un comportement digestif et métabolique voisin de celui de l'adulte). Quel que soit l'âge de l'animal, l'ingestion d'ensilage s'accompagne d'un accroissement de l'efficacité énergétique de la ration dont peuvent rendre compte:

\section{I. - Le développement histo-anatomique du rumen}

Le développement allométrique très nettement positif de cet organe est plus important toutes les fois que figure de l'ensilage dans le régime. Ce développement est en relation avec l'énergie ingérée dont l'efficacité pour l'élaboration des tissus ruminaux est, par ordre croissant : Ensilage préfané $>$ Ensilage naturel $>$ Foin

Par rapport au foin, l'ensilage stimule la formation de papilles de tailles plus importantes et histologiquement plus évoluées (stratum granulosum et corneum plus développés, corps papillaires plus nombreux et plus larges). Nous avons prouvé la liaison entre cette stimulation du développement histo-anatomique du rumen et un accroissement de la capacité d'absorption de l'organe.

\section{2. - Le comportement alimentaire des animaux}

Nous avons mis en évidence, par rapport au foin, certains effets spécifiques de l'ensilage sur le comportement alimentaire des animaux dont les plus marquants concernent la répartition nycthémérale de la prise de nourriture (fractionnement de l'ingestion d'ensilage en la répartissant sur tout le nycthémère) et le comportement mérycique (effet stimulant de l'ensilage sur la motricité du complexe gastrique : augmentation de la durée de rumination rapportée à la matière sèche ingérée, accroissement du nombre de sycles méryciques, diminution de la durée moyenne de ces cycles).

\section{3. - La nature et/ou l'intensité de la digestion ruminale}

En comparaison avec le foin, les modifications importantes de composition et de structure des fourrages au cours de l'ensilage conduisent à la présence dans le rumen de quantités plus importantes de certains métabolites entrant en contact a vec l'épithélium ruminal. L'ammoniogenèse ruminale et la production d'acides gras volatils sont accrues. Les fermentations avec des régimes ensilages ont, par ailleurs, une orientation butyrique marquée qui se fait au détriment de l'acide propionique. En conséquence, les concentrations en acides volatils totaux, en acide 
acétique, en acide propionique et en acide butyrique des jus de rumen des animaux ingérant un fourrage ensilé après préfanage sont nettement plus élevées que celles des contenus des autres lots et, par rapport à celle du foin, l'ingestion d'ensilage naturel se traduit par une concentration ruminale plus élevée en acides gras volatils totaux, en acide acétique et en acide butyrique et plus faible en acide propionique.

\section{SUMMARY}

\section{EFFECT OF LUCERNE SIIAGE INTAKE UPON THE DIGESTIVE PHYSIOLOGY IN THE EARL, $\mathrm{Y}$-WEANED CALF}

Diets containing silage (direct or wilted silage) or hay as sole roughage for the early weaned calf were compared. Whatever the diet used, the age of $x_{4}$ weeks appears to be important in the development of the digestive physiology in the early-weaned calf (5 weeks) (from this age, the young ruminant has a digestive and metabolic behaviour similar to that of the adult). Whatever the age of the animal the silage intake involves an increase in the energy efficiency of the diet. This may result from :

\section{I. - The histo-anatomical development of the rumen}

The allometric development of this organ is clearly positive and is larger as often as silage appears in the diet. This development is connected with the intake of energy, whose efficiency for the elaboration of ruminal tissues can be classified according to the following increasing order :

Wilted silage $>$ Direct silage $>$ Hay

In comparison with hay, silage stimulates the formation of larger papillae with a more advanced histological structure (stratum granulosum and corneum more developed, papillary bodies more numerous and wider). We proved the relationship between this stimulation of the histo-anatomical development and the increase in the absorptive ability of the rumen.

\section{2. - Feeding behaviour of the animals}

In comparison with hay, we showed some specific effects of silage on the feeding behaviour of the animals. The most important ones concerned the circadian distribution of the feed intake (silage intake was distributed over the whole circadian period) and the merycic behaviour (stimulatory effect of silage on the motility of the ruminant stomach; increase in rumination time as related to dry matter intake, increase in the number of cycles of rumination, decrease in the mean duration of these cycles).

\section{3. - The kind and/or intensity of ruminal digestion}

In comparison with hay, the large changes in the composition and structure of roughages during silage lead to the presence in the rumen of higher amounts of some nutrients coming into contact with the ruminal epithelium. The production of ammonia and volatile fatty acids in the rumen are increased. In addition, fermentations with silage diets have a pronounced butyric orientation to the detriment of propionic acid. Consequently, rumen juice concentrations of total volatile fatty acids, acetic acid, propionic acid and butyric acid in animals eating wilted silage are higher than those of juices proceeding from other treatments and, as compared to hay, the intake of direct silage leads to a higher ruminal concentration of total volatile fatty acids, acetic and butyric acid and a lower propionic acid content. 